\title{
Penyuluhan Kesuburan Tanah, Pupuk Organik serta Hama dan Penyakit Tanaman bagi Kelompok Tani Baranuri
}

\author{
Charly Mutiara*, Yustina Maria Silvia Wonga Puu, Donatus Rendo, Josina I.B. Hutubessy \\ Fakultas Pertanian, Universitas Flores, Ende, Nusa Tenggara Timur \\ *Correspoding Author : charlyinter1988@gmail.com \\ Dikirim: 20-10-2020; Diterima: 09-12-2021
}

\begin{abstract}
ABSTRAK
Kelompok Tani Baranuri (KT. Baranuri) merupakan salah satu penyedia sayur mayur bagi masyarakat di Kota Ende. Berdasarkan hasil wawancara dengan para petani diperoleh beberapa permasalahan yaitu belum ada data kesuburan tanah dan kurangnya pemahaman tentang kesuburan tanah, pupuk organik, serta hama dan penyakit tanaman. Solusi yang diberikan yaitu dengan melakukan analisis $\mathrm{pH}$ dan $\mathrm{C}$-organik tanah untuk dijadikan acuan kondisi kesuburan tanah serta penyuluhan tentang kesuburan tanah, pupuk organik, serta hama dan penyakit tanaman. Kegiatan pengabdian ini bertujuan untuk memberikan informasi kesuburan tanah dan menambah pengetahuan petani terkait kesuburan tanah, pupuk organik, serta hama dan penyakit tanaman. Metode penyuluhan yang dipakai adalah pendekatan kelompok. Pengambilan sampel tanah secara purposif, sampel diambil secara diagonal. Kandungan C-organik dianalisis di laboratorium dengan metode Walkley and Black sedangkan $\mathrm{pH}$ tanah dilakukan pengukuran langsung di lapangan menggunakan Soil Survey Instrument 4 in 1 kemudian dilakukan matching dengan kriteria penilaian hasil analisis tanah Balai Penelitian Tanah. Hasil yang diperoleh yaitu tanah memiliki $\mathrm{pH} 4-5$ (sangat masam) dan kandungan C-Organik 2,03-2,37\% (sedang). Kegiatan penyuluhan yang dilakukan berhasil meningkatkan pengetahuan masyarakat dari 46,7\% menjadi $86,7 \%$ (peningkatan sebesar $85,7 \%$ ). Rekomendasi dari kegiatan ini adalah perlunya kebun contoh untuk mengaplikasikan pupuk organik sehingga dapat diamati secara langsung oleh kelompok tani.
\end{abstract}

Kata kunci: C-organik, kesuburan tanah, pH tanah, sampel purposif

\section{Counseling of Soil Fertility, Organic Fertilizers, Pests and Plant Diseases for Baranuri Farmers Group}

\begin{abstract}
The Baranuri Farmers Group (KT. Baranuri) is one of the providers of vegetables for the people of Ende City. The results of interviews with farmers obtained several problems, namely, there is no data on soil fertility and lack of understanding of soil fertility, organic fertilizers, pests and plant diseases. The solution given is to analyze soil $\mathrm{pH}$ and organic-C to be used as a reference for soil fertility conditions as well as counseling about soil fertility, organic fertilizers, pests and plant diseases. This service activity aims to provide information on soil fertility, increase farmers' knowledge regarding soil fertility, organic fertilizers and plant pests and diseases. The counseling method used is a group approach. Purposive soil sampling, samples were taken diagonally. The organic-C content was analyzed in the laboratory by Walkley and Black method, while soil pH was measured directly on the field using 4 in 1 Soil Survey Instrument and then matching with the criteria of assessment of soil analysis results by the Indonesian Soil Research Institute. The results obtained were the soil pH was 4-5 (very acidic-acidic) and soil organic C was 2.03-2.37\% (moderate). The extension activities were succeeded in increasing public knowledge from $46.7 \%$ to $86.7 \%$ (an increase of $85.7 \%$ ). The recommendation from this activity is to create a demonstration field to apply an organic fertilizer that can be observed directly by farmer groups.
\end{abstract}

Keywords: organic C, purposive sampling, soil fertility, soil $\mathrm{pH}$ 


\section{PENDAHULUAN}

Kelompok Tani Baranuri (KT Baranuri) adalah salah satu kelompok tani yang tergabung dalam Gapoktan Pemba Pawe dan bertempat di Kelurahan Rewarangga Selatan, Kecamatan Ende Timur, Kabupaten Ende. Kelompok tani ini berdiri pada tahun 2014 dengan jumlah anggota 18 orang. Kegiatan bersama yang dilakukan kelompok yaitu gotong royong dalam pengolahan lahan setiap musim tanam. Gotong royong sudah menjadi budaya terutama di kalangan petani (Derung, 2019). Peralatan yang biasa dipakai secara bersama-sama dalam kerja kelompok yaitu seperti traktor, mesin pemotong rumput, dan alat semprot.

Jenis tanaman budidaya di kelompok tani ini beraneka ragam antara lain bayam, sawi, kangkung, terung, kacang panjang, cabai, mentimun, dan jagung manis. Kelompok tani ini merupakan salah satu penyedia sayur mayur bagi masyarakat di daerah perkotaan di Kabupaten Ende. Hal ini ditunjang dengan luas areal garapan kelompok yang cukup luas (5 ha) dan letaknya yang berada di daerah perkotaan. Dengan komoditas hasil tanaman pertanian yang beragam dan menjadi salah satu penyedia sayuran bagi masyarakat perkotaan, maka keberadaan KT Baranuri sangat penting. Namun dalam pelaksanaan budidaya tanaman, mereka mengalami beberapa permasalahan. Berdasarkan hasil wawancara di lapangan belum ada data tentang kondisi kesuburan tanah. Data tersebut menjadi panduan dalam pengelolaan lahan untuk meningkatkan kesuburan tanah (Nurlina et al., 2021; Rahmaniah et al., 2021). Selain itu, para petani juga kurang memahami tentang kesuburan tanah, pupuk organik, serta hama dan penyakit tanaman.

Aktivitas pertanian oleh para petani di KT Baranuri sangat intensif sehingga berdampak pada kandungan C-organik tanah yang semakin rendah dan penurunan $\mathrm{pH}$ tanah (Mutiara \& Bolly, 2019). Intensifikasi pertanian terutama pemakaian pupuk dan pestisida anorganik dosis tinggi berdampak pada pencemaran tanah serta sayur yang dibudidayakan. Hasil penelitian (Mutiara, 2014) menunjukkan penggunaan pupuk SP-36 dalam budidaya sayuran, menyebabkan tanah dan sayuran tersebut terkontaminasi logam berat kadmium. Penggunaan pupuk anorganik secara terusmenerus menyebabkan degradasi tanah sehingga kesuburan dan produktivitas menjadi rendah (Minardi et al., 2014; Nazari et al., 2012).
Untuk mengatasi permasalahan tersebut perlu penyuluhan bagi para petani KT Baranuri yang diharapkan dapat memberikan informasi data kesuburan tanah dan menambah pengetahuan petani terkait kesuburan tanah, pupuk organik, serta hama dan penyakit tanaman.

\section{METODE}

Pengabdian kepada masyarakat di KT Baranuri Kelurahan Rewarangga Selatan dilaksanakan dari bulan Mei sampai Agustus 2021. Kegiatan ini melibatkan empat dosen dan 10 mahasiswa Fakultas Pertanian serta lima belas orang anggota Kelompok Tani Baranuri. Penyuluhan menggunakan metode pendekatan kelompok yang menekankan adanya umpan balik dan interaksi aktif dari kelompok terhadap materi penyuluhan yang disampaikan penyuluh (Rasyid, 2012; Rubiantoro \& Haryanto, 2013).

Kegiatan pengabdian dilaksanakan melalui beberapa tahap yaitu meliputi survei dan wawancara dengan pengurus kelompok (Gambar 1), analisis pH tanah dan C-organik di lapangan dan laboratorium, penyuluhan tentang hasil analisis tanah dan kaitannya dengan kesuburan tanah dan tanaman, pupuk organik, serta hama dan penyakit tanaman. Penyuluhan dilakukan dengan metode ceramah dan diskusi kelompok sehingga diperoleh informasi timbal balik dari para petani dan bisa menghasilkan rekomendasi tindak lanjut. Setelah itu dilakukan evaluasi program.

Evaluasi program dilakukan dengan cara menilai tingkat pemahaman petani terkait materi penyuluhan melalui pre-test dan post-test. Hasil kegiatan test tersebut disajikan dalam bentuk grafik.

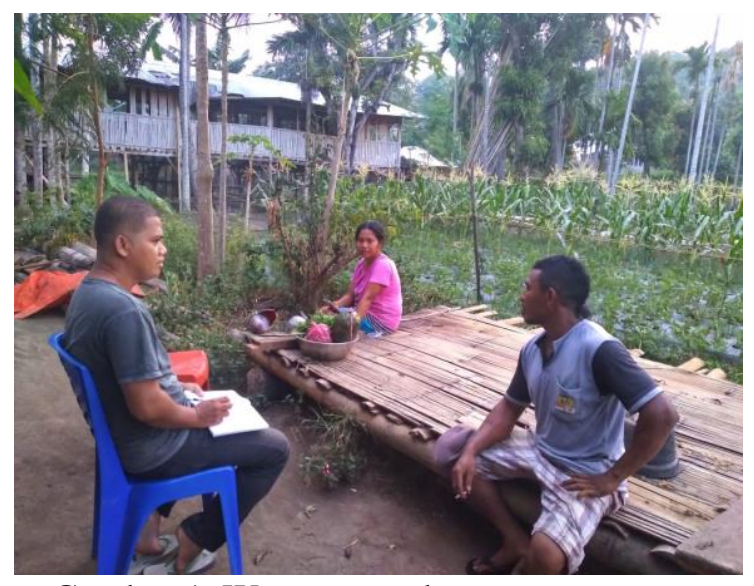

Gambar 1. Wawancara dengan pengurus Kelompok Tani Baranuri 


\section{HASIL DAN PEMBAHASAN}

\section{Survei dan Wawancara}

Survei telah dilakukan pada awal kegiatan pengabdian pada lahan-lahan pertanian di areal perkotaan Kabupaten Ende. Hasil survei menunjukkan bahwa lahan pertanian cukup luas di Kelurahan Rewarangga Selatan dan salah satu kelompok tani pengelola lahan pertanian tersebut adalah KT Baranuri. Hasil wawancara berupa beberapa informasi tentang permasalahan-permasalahan para petani dalam budidaya tanaman, antara lain belum memahami tentang kesuburan tanah, pupuk organik, serta hama dan penyakit tanaman. Selain itu para petani juga belum memiliki data kesuburan tanah dari lahan pertanian yang mereka kelola. Hasil lain kegiatan wawancara adalah kesepakatan terkait waktu dan tempat pelaksanaan kegiatan penyuluhan. Selain itu dalam tahapan awal ini juga dilakukan pengambilan sampel tanah untuk analisis sifat kimia (Gambar 2) yang akan disampaikan dalam kegiatan penyuluhan.

\section{Analisis tingkat keasaman (pH) dan kandungan C-organik Tanah}

Analisis kimia tanah dari kebun para petani yaitu $\mathrm{pH}$ dan kandungan C-organik. Sampel tanah diperoleh menggunakan metode purposive sampling berdasarkan jenis tanaman yang banyak dibudidayakan (bayam, kangkung, dan sawi hijau) dan sistem bera. Budidaya tanaman tersebut selalu menggunakan pupuk anorganik dan tidak pernah menerapkan sistem bera. Berdasarkan metode ini, luasan lahan yang menjadi lokasi pengambilan sampel tanah $\pm 1 \mathrm{Ha}$ dan tanah diambil secara diagonal sehingga diperoleh 9 sampel tanah (Widowati et al., 2018) yang diambil dengan teknik pengambilan contoh tanah terganggu. Pengukuran $\mathrm{pH}$ tanah dilakukan langsung di lapangan dengan menggunakan alat survei tanah (Soil Survey Instrument 4 in 1). C-organik ditetapkan dengan metode Walkley dan Black. Kedua data sifat kimia tanah tersebut sangat penting diketahui para petani karena sebagai sebagian tolok ukur kesuburan tanah dan tanaman (Palupi, 2015; Rahmaniah et al., 2021).

Berdasarkan kriteria penilaian hasil analisis tanah (Balai Penelitian Tanah), hasil analisis menunjukkan bahwa tanah memiliki $\mathrm{pH}$ 4 - 5 (sangat masam-masam). Sedangkan kandungan C-organik tanah 2,03-2,37\% atau berada pada kategori sedang. Kondisi $\mathrm{pH}$ tanah yang masam ini dipengaruhi oleh intensitas aktivitas pertanian yang tinggi dengan selalu menggunakan pupuk anorganik (Mutiara \& Bolly, 2019). Hasil penelitian (Kaya, 2014) menunjukkan bahwa lahan pertanian dengan penggunaan pupuk organik memiliki $\mathrm{pH}$ agak masam sampai netral. Kondisi tanah yang belum optimal juga terlihat dari kandungan C-organik yang rendah. Hal ini disebabkan karena para petani hanya menggunakan pupuk anorganik (Padmanabha et al., 2014).

\section{Penyuluhan}

Kegiatan penyuluhan telah dilakukan kepada para petani yang tergabung dalam KT Baranuri. Kegiatan penyuluhan dilakukan dengan metode diskusi. Materi yang didiskusikan adalah tentang kesuburan tanah, pupuk organik, dan hama serta penyakit tanaman.
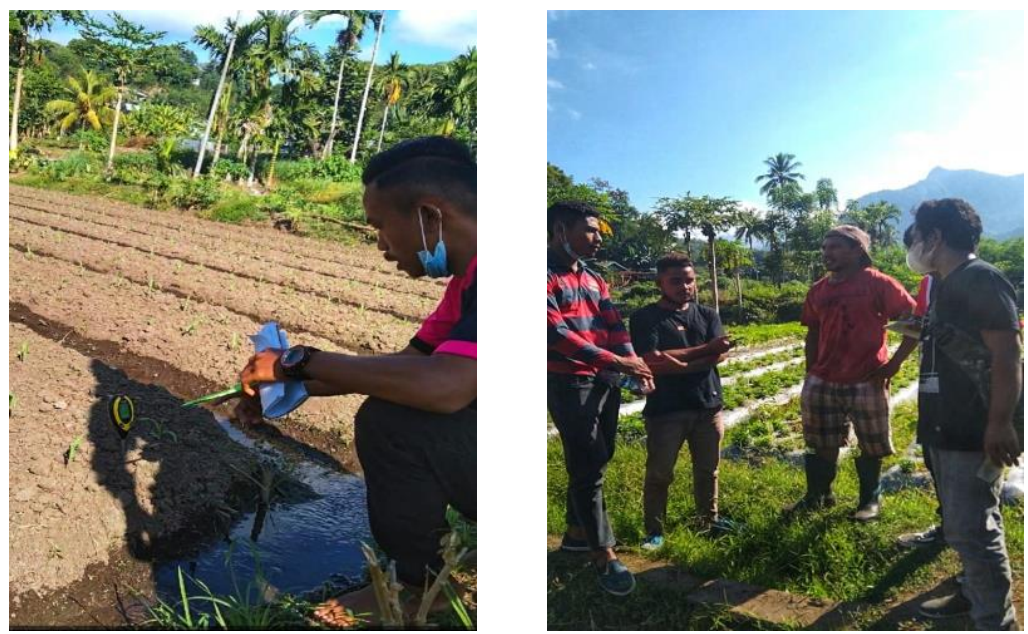

Gambar 2. Diskusi bersama petani untuk pengambilan sampel tanah dan pengukuran $\mathrm{pH}$ tanah 

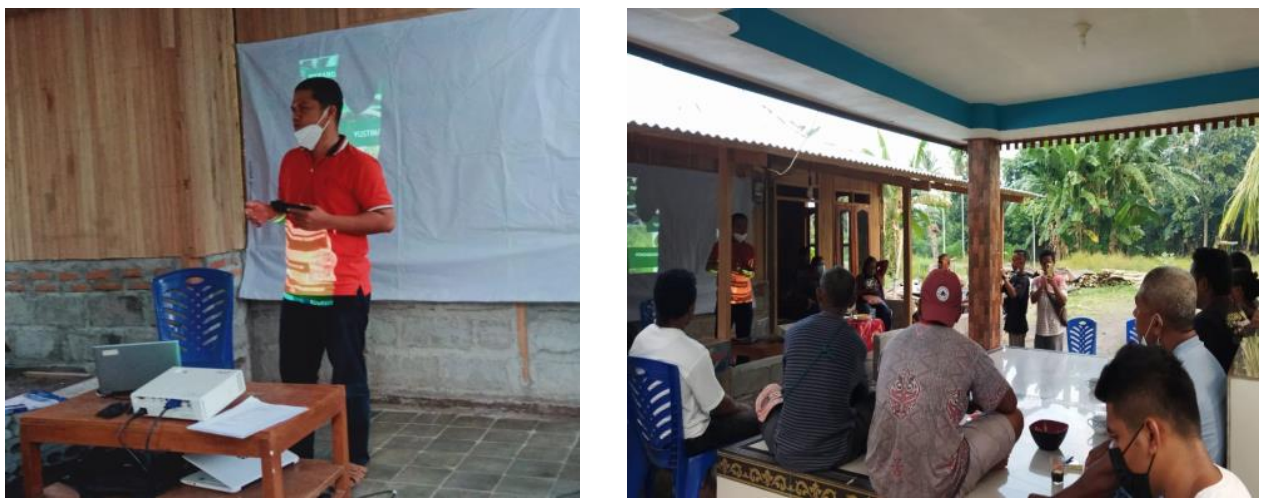

Gambar 3. Penyuluhan tentang pupuk organik

Kesuburan tanah adalah hal yang penting dalam aktivitas budidaya tanaman. Dengan diketahuinya status kesuburan tanah, maka dapat membantu petani dalam meningkatkan produktivitas tanaman sekaligus tetap menjaga keberlanjutan pengelolaan (Soemarno et al., 2021).

Hasil analisis tanah (pH dan C-organik) disampaikan kepada para petani pada saat kegiatan penyuluhan. Respon masyarakat ketika hasil tersebut disampaikan adalah banyak pertanyaan tentang manfaat $\mathrm{pH}$ tanah dan $\mathrm{C}$ organik bagi kesuburan tanah dan tanaman. Manfaat $\mathrm{pH}$ tanah dan C-organik bagi kesuburan tanah dan tanaman adalah menentukan tingkat serapan atau ketersediaan unsur hara bagi tanaman (Neoriky et al., 2017).

Kegiatan penyuluhan tentang pupuk organik diberikan kepada para petani di KT Baranuri oleh para dosen Fakultas Pertanian (Gambar 3). Kegiatan penyuluhan dilakukan dengan metode pendekatan kelompok yang mengutamakan adanya umpan balik, interaksi dari kelompok, serta partisipasi aktif dari kelompok. Hasilnya adalah adanya diskusi dan saling tukar pengalaman antara anggota kelompok dan penyuluh.Berdasarkan hasil diskusi diketahui bahwa para petani sudah sangat sering mendapat penyuluhan tentang pupuk organik. Namun mereka belum mau mencoba karena berpendapat bahwa penggunaan pupuk organik tidak praktis atau merepotkan. Kondisi ini dapat terjadi karena perbandingan dosis pupuk organik dan anorganik yang biasa digunakan kurang lebih 100:1 (Harahap et al., 2020; Padmanabha et al., 2014). Selain itu pupuk organik tidak dimanfaatkan oleh para petani karena belum ada contoh langsung keberhasilan penggunaan pupuk organik oleh petani di sekitarnya.

Penyuluhan terkait hama dan penyakit pada tanaman dilakukan oleh Dosen Fakultas Pertanian (Gambar 4). Pada kegiatan penyuluhan tersebut disampaikan kepada para petani tentang perbedaan hama dan penyakit, ciri-cirinya, serta penanganannya. Hasil penyuluhan dan diskusi yang dilakukan adalah para petani semakin paham tentang hama dan penyakit tanaman yang mereka hadapi. Kondisi ini sejalan dengan kegiatan penyuluhan yang telah dilakukan (Hanafie \& Wahyudi, 2018). Dari kegiatan tersebut diketahui bahwa pengetahuan petani semakin meningkat tentang jenis hama dan penyakit yang menyerang tanamannya serta langkah-langkah pencegahannya.
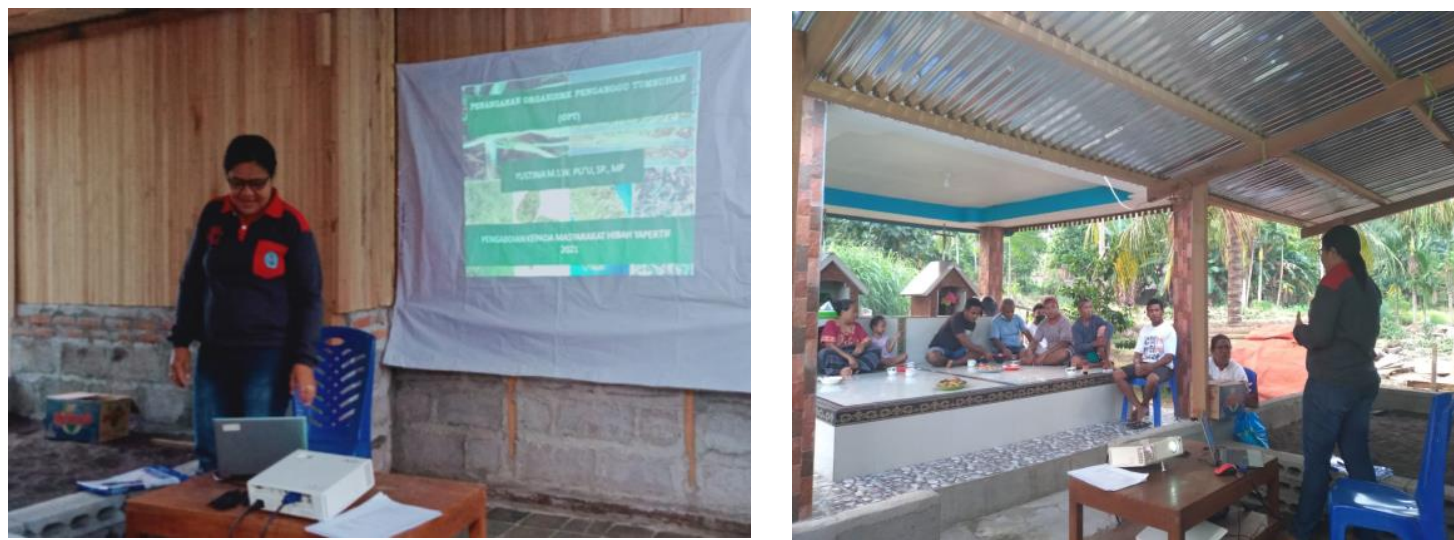

Gambar 4. Penyuluhan hama dan penyakit tanaman 


\section{Evaluasi Kegiatan}

Kegiatan pengabdian kepada masyarakat yang telah dilakukan terhadap para petani di KT. Baranuri dievaluasi tingkat keberhasilannya dengan pre-test dan post-test. Evaluasi ini terkait peningkatan pengetahuan petani tentang kesuburan tanah, pupuk organik, serta hama dan penyakit pada tanaman. Hasil pre-test pada evaluasi kegiatan penyuluhan menunjukkan hanya $46,7 \%$ yang memahami tentang kesuburan tanah, pupuk organik dan hama penyakit tanaman sedangkan saat post-test diperoleh hasil 86,7\% yang memahami (Gambar 5).

Berdasarkan hasil tes yang dilakukan menunjukkan adanya peningkatan pengetahuan petani dari pre-test ke post-test sebesar $85,7 \%$. Hal ini dikarenakan adanya partisipasi aktif ketika penyuluhan dilakukan. Partisipasi aktif para petani terlihat dari diskusi yang dilakukan untuk setiap materi. Kegiatan penyuluhan yang melibatkan partisipasi aktif dari masyarakat akan mudah dimengerti dengan baik (Kurnia et al., 2020; Sankaran \& Demangeot, 2017; Secundo et al., 2017).

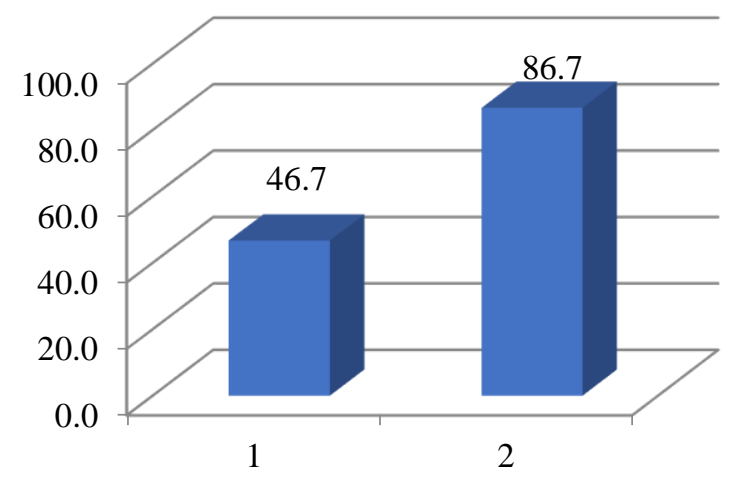

Gambar 5. Presentase pre-test (1) dan posttest (2) pemahaman petani terhadap materi penyuluhan

\section{KESIMPULAN}

Status kesuburan tanah pada lahan pertanian para petani memiliki tingkat kesuburan rendah dengan indikator $\mathrm{pH}$ tanah pada nilai $4-5$ (sangat masam-masam) dan kandungan Corganik 2,03-2,37\% (sedang). Kegiatan penyuluhan yang diberikan berhasil meningkatkan pengetahuan masyarakat terhadap materi penyuluhan yang diberikan yaitu dari $46,7 \%$ menjadi $86,7 \%$ (peningkatan sebesar $85,7 \%$ ). Selain itu, dari kegiatan ini menghasilkan rekomendasi bahwa diperlukan kebun contoh untuk mengaplikasikan pupuk organik, sehingga dapat diamati secara langsung oleh para petani.

\section{UCAPAN TERIMA KASIH}

Penulis mengucapkan terima kasih kepada Yayasan Perguruan Tinggi Flores dan Lembaga Penelitian dan Pengabdian Kepada Masyarakat Universitas Flores yang telah mendukung dan membiayai seluruh kegiatan pengabdian ini.

\section{DAFTAR PUSTAKA}

BPT. (2009). Petunjuk Teknis Analisis Kimia Tanah, Tanaman, Air dan Pupuk. Balai Penelitian tanah.

Derung, T. N. (2019). Gotong Royong dan Indonesia. Sapa, 4 No.1, 5-13.

Hanafie, S., \& Wahyudi, I. (2018). PKM kelompok tani sayuran dalam penggunaan teknologi pengelolaan hama dan penyakit ramah lingkungan dan teknologi pemupukan organik untuk meningkatkan produktivitas dan pendapatan petani di Desa Karawana Kecamatan Dolo Kabupaten Sigi. Abditani, 1(1), 50-57. https://doi.org/10.31970/abditani.v1i0.7

Harahap, R., Gusmeizal, \& Pane, E. (2020). Efektifikatas kombinasi pupuk kompos kubis-kubisan (Brassicaceae) dan pupuk organik cair bonggol pisang terhadap produksi kacang panjang (Vigna Sinensis L.). Jurnal Ilmiah Pertanian, 2(2), 135143.

Kaya, E. (2014). Pengaruh pupuk organik dan pupuk NPK terhadap $\mathrm{pH}$ dan K-tersedia tanah serta serapan-K, pertumbuhan, dan hasil padi sawah (Oryza sativa L). Buana Sains, 14(2), 113-122.

Kurnia, M., Jaya, I., Jalil, A. R., Arya, N., \& Amin, S. (2020). KKN tematik pemberdayaan masyarakat melalui penerapan teknologi untuk peningkatan taraf hidup masyarakat di Kecamatan Pulau Sembilan Kabupaten Sinjai. Jurnal Pengabdian Masyarakat Hasanuddin, 1(1), 1-9.

Minardi, S., Hartati, S., \& Pardono. (2014). Imbangan pupuk organik dan anorganik pengaruhnya terhadap hara pembatas dan kesuburan tanah lahan sawah bekas galian $\mathrm{C}$ pada hasil jagung (Zea mays L.). Sains Tanah, 11(2), 122-129. https://doi.org/10.15608\%2Fstjssa.v11i2.2 28

Mutiara, C. (2014). Kandungan kadmium di dalam wortel, bawang prei dan buncis yang ditanam pada tanah berbahan induk kapur 
dan volkanik dengan dosis pupuk $\mathrm{P}$ yang berbeda. Agrica, 7(2), 132-141. https://doi.org/10.37478/agr.v7i2.411

Mutiara, C., \& Bolly, Y. Y. (2019). Identification of agricultural activities and soil fertility in the cultivation area of nuabosi cassava. Caraka Tani: Journal of Sustainable Agriculture, 34(1), 22-30. https://doi.org/10.20961/carakatani.v34i1. 25708

Nazari, Y. A., Soemarno, \& Agustina, L. (2012). Pengelolaan kesuburan tanah pada pertanaman kentang dengan aplikasi pupuk organik dan anorganik. Indonesian Green Technology Journal, 1(1), 7-12.

Neoriky, R., Lukiwati, D. R., \& Kusmiyati, F. (2017). Pengaruh pemberian pupuk anorganik dan organik diperkaya $\mathrm{N}, \mathrm{P}$ organik terhadap serapan hara tanaman Selada (Lactuca sativa. L). Journal of Agro Complex, $\quad 1(2), \quad 72-77$. https://doi.org/10.14710/joac.1.2.72-77

Nurlina, Rahmi, \& Hambali, H. (2021). PKM kelompok tani parang lompoa pada teknologi tepat guna "alat ukur kesuburan tanah" di Tombolopao. Jasintek, 2(2), 103 108. https://doi.org/10.52232/jasintek.v2i2.52

Padmanabha, I. G., Arthagama, I. D. M., \& Dibia, I. N. (2014). Pengaruh dosis pupuk organik dan anorganik terhadap hasil padi (Oryza sativa L.) dan sifat kimia tanah pada inceptisol Kerambitan Tabanan. E-Jurnal Agroekoteknologi Tropika, 3(1), 41-50.

Palupi, N. P. (2015). Analisis kemasaman tanah dan $\mathrm{C}$ organik tanah bervegetasi alang alang akibat pemberian pupuk kandang ayam dan pupuk kandang kambing. Media Sains, 8(2), 182-188.

Rahmaniah, Zulfida, I., \& Oesman, R. (2021). Karakteristik status kesuburan tanah pada lahan pekarangan dan lahan usahan tani di Kecamatan Rantau Selatan. Journal Liaison of Academia and Society, 1(1), 118.

Rasyid, A. (2012). Metode komunikasi penyuluhan pada petani sawah. Jurnal Ilmu Komunikasi, 1(1), 31-35.

Rubiantoro, E. A., \& Haryanto, R. (2013). Bentuk keterlibatan masyarakat dalam upaya penghijauan pada kawasan hunian padat di Kelurahan Serengan - Kota Surakarta. Jurnal Pembangunan Wilayah \& Kota, 9(4), 416-428. https://doi.org/10.14710/pwk.v9i4.6679

Sankaran, K., \& Demangeot, C. (2017). Conceptualizing virtual communities as enablers of community-based entrepreneurship and resilience. Journal of Enterprising Communities: People and Places in the Global Economy, 11(1), 7894. https://doi.org/10.1108/JEC-02-20150017

Secundo, G., Vecchio, P. Del, Schiuma, G., \& Passiante, G. (2017). Activating entrepreneurial learning processes for transforming university students' idea into entrepreneurial practices. International Journal of Entrepreneurial Behavior \& Research, 23(3), 365-485. https://doi.org/10.1108/IJEBR-12-20150315

Soemarno, Nisfi, Zahrotun, Rifqy, \& Haidar. (2021). Dasar-Dasar Manajemen Kesuburan Tanah Pertanian (1st ed.). Universitas Brawijaya Press.

Widowati, L. R., Hartatik, W., Setyorini, D., Rosliani, R., \& Sutopo. (2018). Petunjuk Penggunaan Perangkat Uji Tanah Kering (Versi 2.0). Balai Penelitian Tanah-Balai Besar Litbang Sumberdaya Lahan pertanian. 